\title{
NEW CONTRIBUTIONS TO THE KNOWLEDGE OF HONEY BEE (APIS MELLIFERA) PESTS
}

\author{
Svetlana Bacal
}

Institute of Zoology, Chișinău, Republic of Moldova, e-mail: svetabacal@yanhoo.com

\begin{abstract}
The paper aimed to identify the pest complex facing Apis mellifera, in autumn and winter, based on an apiary in Tomai, Leova district. In the presence of pests, 60 bee families were checked during the sanitation and feeding work of the bees, between April and May. A total of 3 species of pests have been identified, that cause damage to bees and honeycombs. Each identified species also contains information on the origin of the species, diet, range, some biological features, methods of detection and protection against these pests. Strict monitoring of pests can help to avoid negative effects on apiaries without losing bee families and their products.
\end{abstract}

\section{Introduction}

Bees are among the most important pollinating insects of plants cultivated in the world They pollinate over 150 species of cultivated entomophilous plants. Therefore, the plants that are the essential source of life support depend on pollinators. The amount of fruit and seeds obtained per hectare depends directly on the degree of pollination of flowers by insects, including bees [4]. Bees contribute annually to the production of agricultural crops of sunflower, rapeseed, mustard, vegetables, fruits and berries by approx. 9\%, which represents about 153 billion euros in the global economy [1 Bees also offer many bee products such as honey, pollen, propolis, royal jelly, venom and wax [2]. Due to climate change and globalization, bee diseases and pests have become more widespread. The disappearance of bees from nature would have serious consequences for the environment, biodiversity, economy and human life. In addition to pests, bees are also directly affected by environmental factors (cyclonic rains, temperature fluctuations, strong winds). Given the enormous role that bees play in human life, it is absolutely necessary to know and combat their pests. In both the warm and cold periods of the year, bees are affected by various pests. The aim of the research was to highlight the pest complex of honey bees in autumn and winter period.

\section{Materials and methods}

The faunistic material discussed in the paper was collected from the apiary in Tomai, Leova district, in April and May of 2021. The apiary was placed in the household of the beekeeper from the above-mentioned locality. The available literature in this regard was used to identify the species [5]. For the analyzed species, they were also described some aspects from the specialized literature $[5 ; 6 ; 7]$.

\section{Results and discussions}

During the spring work, along with the cleaning of the hives, some bee pests were also collected. The honey bee pests (Apis mellifera) in the researched apiary are represented by 3 species of pests, which belong to 2 classes (Insecta and Arachnida), 3 orders (Lepidoptera, Hy- 
menoptera and Parasitiformes) and 3 families (Varroidae, Sphingidae and Vespidae). Bee pests can be classified depending on the attack they produce such as parasites (arachnida), predators (wasps) and wax pests (butterflies). In order to facilitate the analysis of pests, their presentation was chosen according to the classes they belong. The following is a list of pests identified in the apiary investigated in the cold season of the year:

Class Arachnida

Order Parasitiformes

Family Varroidae

Varroa destroyer Anderson \& Trueman, 2000. Originally from Southeast Asia (Java, Indonesia), it was first described in 1904 by A. C. Oudemans, as V. jacobsoni. In the Republic of Moldova, Varroa destructor has been present since 1964 in all bee families from all apiaries (previously identified as V. jacobsoni) [7]. Adults feed on the hemolymph of adult bees and larvae. Females live throughout the year, males between 15-20 days. From a single female in the hive, a population grows to 30 thousand individuals [5]. The parasite has a strong economic impact on the beekeeping industry.

There are numerous methods of collecting the parasite, the most harmless methods were used without destroying the bees: the powdered sugar method and the sticky surfaces method. Interpretation of results. If there are 10 varroa parasites per 100 bees analyzed, the infection is considered weak, up to 20 parasites - medium, and more than 20 parasites denote a strong infection. In the absence of immediate treatment, the entire bee colony can be destroyed [7]. Following the study of the apiary, more than 10 mites per 100 bees were found. The main methods of treating varroatosis are: chemical treatment, zootechnical measures, heat treatment and their combinations. In order to prevent the spread of the parasite, epizootic monitoring of mite invasion and preventive treatment of bee colonies are constantly performed.

Class Insect

Order Lepidoptera

Family Sphingidae

Acherontia atropos Linnaeus, 1758 (African death's-head hawkmoth). Originally from North Africa, now widespread in Europe, the European part of Russia, the Middle East, Africa. It is a migratory species. In years with mild climates, some specimens can survive and multiply. It is a polyphagous butterfly, the adults feed on the sap of the trees and the juice of the ripe fruits, but they also enter the hives of the bees and consume 5-10 grams of honey, until they are detected by the bees and killed. Death's-head butterfly is a large butterfly $50 \mathrm{~mm}$ long, with a pair of brown wings, and the other pair - yellow with two black stripes. The basic feature is the presence of the skull shell design on the thorax. The male is smaller than the female. After mating, females lay eggs on the leaves of different plant species. It can be found in various agricultural crops (potato - Solanum tuberosum), as well as in shrub plantations (oleander - Nerium oleander, raspberry - Rubus idaeus, jasmine - Jasminum officinale, euonymus - Euonymus europaeus, etc.). There are two generations per year (May-July; September-October) [5]. Only one specimen was found. It is a rare species. Does not cause damage to apiaries. 


\section{Order Hymenoptera}

Family Vespidae

Vespula germanica (Fabricius, 1793), originating from Europe, North Africa and temperate Asia. They are polyphagous predators that feed on various arthropods, fruits, honey, meat with body dimensions reaching $12-15 \mathrm{~mm}$ in length and are black and yellow. They build their nests from vegetation chewed with saliva, most often in the soil, sometimes on the surface of the soil, and other times in attics. Prefers forested areas. In the spring, the queen lays the eggs, from which appear working individuals. At the end of summer, appear males and females which will become queens. The latter are wintering. A colony can exceed 10,000 individuals, but their number depends on climatic conditions. 7 individuals were detected in the analyzed apiary. The specialized literature confirms the entry of the pest into the hives to steal honey [3].

The study was carried out within the project 20.80009.7007.12:

\section{Conclusions}

During the spring work, along with the cleaning of the hives, three species of bee pests were collected and identified (Varroa destructor, Vespula germanica, Acherontia atropos). According to observations, the biggest danger to the apiary is represented by Varroa destructor mites, which negatively affected the health of bees, which will influence the production of honey. This negatively affects not only the quality and quantity of bee products, but also involves serious problems in agriculture, because bees are the main pollinators of agricultural crops. Our observations can be used by beekeepers in the fight against pests in apiaries.

\section{Bibliography}

1. Gallai N., Salles J-M., Settele J., Vaissière B.E. Economic valuation of the vulnerability of world agriculture confronted with pollinator decline. Ecological Economics, Elsevier, 2009. 68 (3). p. 810-821.

2. Lazăr Şt., Vornicu C.O. Apicultura, Editura Alfa, 2007, 656 p.

3. Pusceddu M., Floris I., Buffa F., Salaris E., Satta A. Agonistic interactions between the honeybee (Apis mellifera ligustica) and the European wasp (Vespula germanica) reveal context-dependent defense strategies. Plos one, 05 Jul 2017, 12(7): e0180278. DOI: 10.1371/journal. pone.0180278.

4. Важов В.М., Панков Д.М. Проблемы опыления сельскохозяйственных культур в Алтайском крае Материалы международной научной конференции Тайланд (Бангкок, Паттайа) 20-30 декабря, 2009 г. Современные наукоемкие технологии. - 2009. 12. с. 3133.

5. Гробов О.Ф., Смирнов А.М., Попов Е.Т. Болезни и вредители медоносных пчел: Справочник. М.: Агропромиздат. 1987. 335 с.

6. Коновалова Т.В. Видовой состав ос-вредителей медоносной пчелы Apis mellifera. Ветеринария и Кормление. г. Москва. 2018. с. 28-31.

7. Садовникова Е. Ф. Варроатоз пчел: рекомендации. Е. Ф. Садовникова, В. Н. Гиско, Е. М. Панькив. Витебск: ВГАВМ. 2019. 32 с. 